\title{
Islamic Banking Service Quality and Deposit Withdrawal Risk: Evidence from Brunei Darussalam
}

\author{
Muhamad Abduh ${ }^{1}$
}

\begin{abstract}
This paper aims to evaluate the service quality of Islamic banking and to explore the withdrawal behavior of Islamic banking depositors based on their evaluation towards its service quality in the context of Brunei Darussalam. A total of 180 Islamic banking customers in Brunei Darussalam were involved through a direct survey. Factor analysis is used to uncover the key dimensions of Brunei Islamic banking service quality. Afterwards, the importance and performance analysis (IPA) was employed to evaluate the importance and performance level of Brunei Islamic banking service quality. The five key dimensions of Brunei Islamic banking service quality uncovered here including assurance, reliability, tangibles, empathy, and rates and charges. Interestingly, only three dimensions survive and two are rated high in importance and low in performance. These are empathy and rates and charges. Therefore, bank management is required to give more attention and priority on how to improve the situation.
\end{abstract}

Keywords: service quality, deposit withdrawal, Islamic banking, Brunei Darussalam.

\section{Introduction}

Fifty years ago, Egyptian Mit-Ghamr bank was set up as the first Islamic bank in the history of modern economy. The world is now witnessing tremendous growth of the industry especially for the last two decades. The IFSI Stability Report of IFSB (2016) recorded that the global Islamic financial services industry reached an overall total value of USD1.88 trillion as of 2015. The Islamic banking sector continues to be the dominant segment of banking. The report has also mentioned that Islamic banking sector accounts for almost $80 \%$ of the global Islamic financial services industry. Assets in full-fledged Islamic banks, subsidiaries and windows amount to approximately USD1.5 trillion as at first half of 2015.

Brunei Darussalam is a pioneering country in Islamic banking. Bank Islam Brunei Darussalam is the only bank in Brunei Darussalam that serves all sectors and segments within the retail banking market. The bank started operations in 1981 as the Island Development Bank. It was converted to a full-fledged Islamic bank in January 1993 and changed its name to Islamic Bank of Brunei. Through a merger with Islamic Development Bank of Brunei, Bank Islam Brunei Darussalam was formed in 2005.

${ }^{1}$ Assistant Professor at School of Business and Economics, Universiti Brunei

Darussalam JalanTungku Link, Gadong, Brunei Darussalam

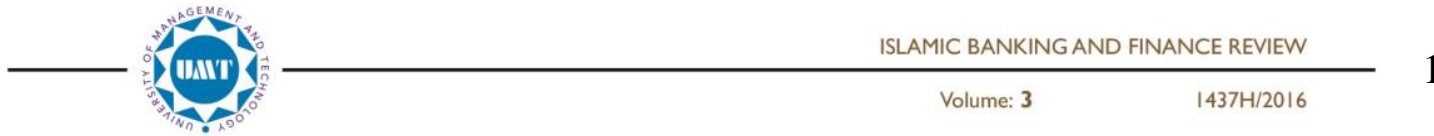


Despite Islam as the official religion of the country and the religion of majority of the Bruneian, the understanding about riba is still low. Particularly young people, working or studying at universities are unaware of riba. Furthermore, Islamic and conventional banks operating in Brunei are offering similar products and following almost similar regulations set by the monetary authority of Brunei Darussalam. Abduh (2011) claimed that if the banks offer more or less similar products / services and competition intensifies, it is the customer's satisfaction on service quality that influence the performance of an Islamic bank and determine its success. Therefore, it is very important to evaluate and improve the service quality of Islamic banking, particularly in Brunei Darussalam. Since Islamic banking's foci is on profit and loss sharing, hence, in order to be successful it has to keep deposits stable and in a large volume (Abduh, 2011).

The present research study is an attempt to make two major contributions. Firstly, although Islamic banking industry started more than 20 years ago in Brunei Darussalam, academic studies related to the development of the industry are still scant, especially studies pertaining to the behavior of customers. Therefore, this paper is expected to significantly contribute in the literature of Islamic banking in Brunei. Secondly, unlike its conventional counterpart, Islamic principles forbid Islamic banks to take any interest-based income and thus make deposits an important source of fund for operation and financing. The situation is worsened and creates withdrawal risk when other banks offering higher return on deposits (Abduh, 2014). This paper provides insights on withdrawal behavior of Islamic banking customers in Brunei Darussalam.

\subsection{Service Quality}

\section{Literature Review}

Parasuraman, et.al. (1990) mentioned that service quality is an extrinsically perceived attribution based on the customer's experience about the service. Service quality is not only involved in the final product and service, but also involved in the production and delivery process. Thus employee involvement in process, redesign and commitment is important to produce final products or services.

Due to cultural differences, various dimensions of service quality have been revealed in this area of study. Parasuraman et al. (1985), for instance, identified 11 dimensions of service quality; reliability, responsiveness, competence, access, courtesy, communication, credibility, security, competence, understanding the customer, and tangibles. Berry et al. (1985) and Zeithaml and Bitner (1996) indicated that service quality consists of five dimensions: tangibles, reliability, responsiveness, assurance, and empathy. In the area of Islamic banking, the study done by Abduh (2011) reveals five key dimensions of Indonesian Islamic banking service quality, including reliability, bank-customer relationship, tangibles, shari ${ }^{2}$ is issues, and rates and charges. 


\subsection{Customer Satisfaction and Withdrawal Risk}

Bolton and Bronkhurst (1995) defined the switching behavior as the decision of a customer to stop purchasing particular services or patronizing the service completely. Abduh (2014) argued that to date, the term switching behavior is used inter- changeably with withdrawal behavior. However, Ahmed (2002) argued that the term withdrawal behavior is more appropriate to be used in Islamic banking framework due to the fact that Islamic banking has two types of customer; clients with account in only Islamic bank and clients with accounts in both Islamic and conventional banks. For religious customers, switching to conventional banks is not an option as it is against their faith, and thus the term withdrawal behavior is better to be used here.

There are not many studies on the relationship between customer satisfaction and withdrawal action in the area of Islamic banking and finance. The study done by Abduh (2011) explained five key dimensions of Islamic banking service quality in Indonesia. These are; reliability, bank-customer relationship, tangibles, shari ah issues, and rates and charges. Interestingly, shari ah and tangible are declared as the most influential factors for Indonesians to withdraw their funds from Islamic bank. The study also found that despite their high level of importance, shari ah and tangible were perceived poor in performance. Therefore, withdrawal risk exists and should be mitigated properly.

In Indonesia, Suryani and Chaniago (2011) conducted a field survey among Islamic bank customers in Surabaya city. The survey aimed to find causes of switching behavior of the Islamic bank customers. By using exploratory factor analysis, the results indicated that there are five factors underlying customer switching behavior in Islamic banking services. These are; bank-customer relationship, Shari'ah compliance issues, service quality, switching cost and risk perceived by the customers. Abduh et.al. (2012) investigated the dimensions of customer satisfaction in Indonesia Islamic banking industry and how those dimensions could affect the customers' switching behavior. Respondents involved were 732 Islamic bank customers from the area of Jakarta. The methods used were factor analysis and logistic regression model. Factor analysis successfully uncovered the five dimensions of Indonesia Islamic banking customer satisfaction. These dimensions are; profitability, bank staff, accessibility, costs, and bank's physical appearance. Afterwards, logistic regression evidenced that four dimensions are significantly affecting Islamic bank customers' intention to switch to other banks. These were; bank staff, bank's physical appearance, accessibility, and costs. Surprisingly, profitability was perceived less important by respondents with regard to bank-switching issues.

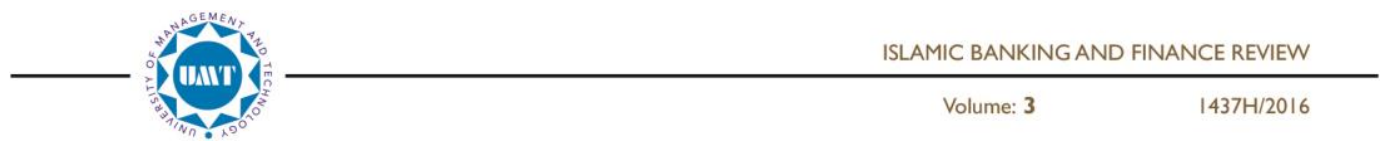


Another study was done in Malaysia by Abduh et.al (2013) with the objective to evaluate factors causing switching behavior of Islamic banking customers, in the case of Malaysia, based on the Shari'ah compliance issues. Using logistic regression, the results showed that the customer's religion, type of account, and whether or not s/he have account in conventional bank are the significant factors to influence their switching behavior when they encounter non-Shari'ah compliant products and practices in their Islamic bank.

\section{Data Collection and Methods of Analysis}

\subsection{Data Collection}

Primary data used in this study was collected using 300 self-administered questionnaires. The questionnaires were distributed among Islamic bank customers in Bandar Seri Begawan from January 2016 to June 2016. Out of the 300 questionnaires distributed, only 180 questionnaires were dully filled by the respondents. Hence responses of 180 respondents are analyzed in the present study. The collected data consists of fifteen attributes of service quality and demography. Before going to the main analysis, the data will be analyzed using descriptive statistics including crosstabulation chi-squared independent test, cronbach's alpha reliability test, and principle component analysis based factor analysis. The main method of analysis is importance and performance analysis.

\subsection{Importance-Performance Analysis}

Importance and performance analysis (IPA) is the visual-empirical analysis used in this study in order to uncover Bruneian assessment on Islamic banking services. Customers' views are plotted onto importance-performance grids which offer the researcher a straightforward, graphic illustration of service dimensions considered to be salient and well-addressed by current installations of Islamic bank services. The points will fall into one of four quadrants labeled "keep up the good work", "possible overkill, "low priority", and "concentrate here" (see figure 1).

The general understanding of "keep up the good work" is when one point is plotted within the area of high importance and high performance. When one point is viewed less important but too good in performance, it will be plotted in "possible overkill" quadrant, while "low priority" quadrant signifies area with low importance and low performance. Finally, items rated high in importance but low in performance in "concentrate here" quadrant implies that overkill has occurred and therefore, improvement must be done for items plotted here. 

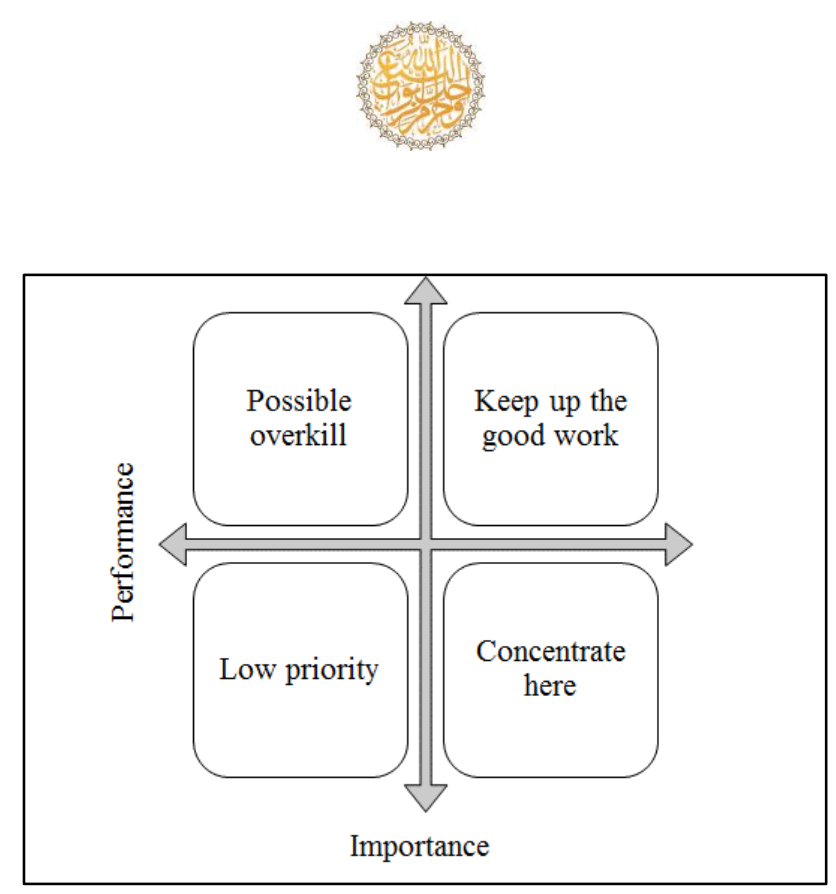

Figure 1. Importance-performance analysis matrix

In order to confirm the level of importance of the 5 dimensions, initially mean importance rating were computed for each dimension. For example, for 'Empathy' dimension, get the mean importance rating from items related to "Empathy". After computing the mean for all dimensions, get the grand mean by dividing the total of mean scores across dimensions by 5 . The dimensions whose averages exceeded the grand mean were labeled as 'high importance' and those with lower means compared with the grand mean were labeled as 'low importance' dimension. Similar procedures were applied to determine the higher and the lower performance.

\section{Findings and Discussion}

\subsection{Descriptive Analysis and Chi-Squared Independent Test}

Table 1 shows the demography of respondents involved in this study. Based on the statistic displayed, 20 percent of the respondents are male and 80 percent are female. The age group shows that 58.3 percent are below 25 years old and 41.1 percent are between 25 and 35 years old. It can be argued here that the study has chosen the right age group distribution since the age groups of the respondents are representing the future customers of banking industry in Brunei Darussalam.

As many as 87.2 percent are Muslims and 96.1 percent are not married. Another important statistic is the respondents' level of education. It is shown in Table 1 that 107 respondents (59.4\%) are postgraduate degree holders and 73 (40.6\%) respondents are undergraduate degree holders.

One of the most important findings in this section is that there is evidence of the existence of religious and rational depositors in Brunei Darussalam. Rational depositors are those who deposited money in both Islamic and conventional banks. By diversifying their investment portfolio, they only expect to get better return from it

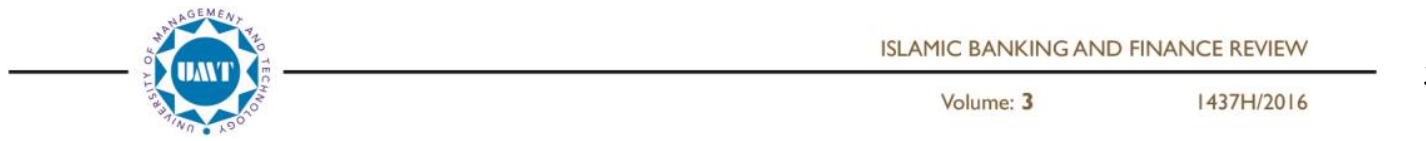


and has never considered Shari'ah issues as the main reason to patronize Islamic bank. Religious depositors, on the other hand consider Shari'ah issues as the main reason to patronize an Islamic bank. According to Table 1, respondents with multiple banking accounts are 107 (59.4\%) and the respondent with single banking account are $73(40.6 \%)$.

Table 1

Demography of Respondents

\begin{tabular}{llcc}
\hline & Variable & Frequency & Percentage (\%) \\
\hline Gender & Male & 36 & 20 \\
\multirow{4}{*}{ Age } & Female & 144 & 80 \\
& $<25$ years & 105 & 58.3 \\
\multirow{4}{*}{ Religion } & $25-35$ years & 74 & 41.1 \\
& $>35$ years & 1 & 0.6 \\
Marital Status & Islam & 157 & 87.2 \\
\multirow{4}{*}{ Level of Education } & Others & 23 & 12.8 \\
& Married & 7 & 3.9 \\
Having conventional & Not Married & 173 & 96.1 \\
bank account & Yndergraduate & 73 & 40.6 \\
& Yostgraduate & 107 & 59.4 \\
& No & 107 & 59.4 \\
\end{tabular}

Abduh (2014) asserted that three main reasons may lead to withdrawal action; non-Shari'ah compliant issues, uncompetitive rate of return, and rumors about incoming global financial crisis that could affect the performance of their patronized Islamic bank. However, due to the fact that Brunei was not really affected by the global financial crises in 1997-1998 and 2007-2008, this study adopted the first two reasons and changed the third reason to service quality problem.

Table 2

Reasons for Withdrawal Action

\begin{tabular}{lccc}
\hline Decision & \multicolumn{3}{c}{ Reason } \\
\hline \multirow{3}{*}{$\begin{array}{l}\text { I will withdraw } \\
\text { I will not withdraw }\end{array}$} & $\begin{array}{c}\text { Non-Shari'ah } \\
\text { compliant issues }\end{array}$ & $\begin{array}{c}\text { Uncompetitive } \\
\text { rate of return }\end{array}$ & $\begin{array}{c}\text { Low service } \\
\text { quality }\end{array}$ \\
\cline { 2 - 4 } Total & $100(55.6 \%)$ & $101(56.1 \%)$ & $143(79.4 \%)$ \\
\cline { 2 - 4 } & $80(44.4 \%)$ & $79(43.9 \%)$ & $37(20.6 \%)$ \\
\hline
\end{tabular}

Table 2 shows the statistic of the main reasons for deposit withdrawal by the respondents. With regard to the issue of non-shari'ah compliant products and 
services, 55.6 percent of the respondents decide to withdraw from Islamic bank while another $44.4 \%$ remain loyal. Meanwhile, 56.1 percent of the respondents say that they will withdraw due to uncompetitive rate of return from Islamic bank and 79.4 percent of the respondents indicate to withdraw due to the issue of low service quality of the bank.

Awareness about the status of bank interest from the Islamic point of view has a significant impact towards the decision of many Muslims on their bank selection in Indonesia, Kazakhstan, and Mauritania respectively (Abduh et.al., 2012; Abduh and Omarov, 2013; Mahmoud and Abduh, 2014). As displayed in Table 3, this paper provides deeper analysis by doing chi-squared independent test via cross tabulation between the respondents' main reasons of patronizing Islamic bank and their deposit withdrawal decision.

Table 3 shows that there is enough evidence to say that respondents who put "to avoid bank interest" as their main reason in patronizing Islamic banks will withdraw their funds if they find out that their Islamic bank is involved with nonShari'ah compliant issues including doubtful products and hidden charges. Similarly, there is statistically significant evidence that respondents who consider Islamic bank as an alternative to gain more profit will withdraw their funds from Islamic bank due to lower rate of return given to them. Interestingly, there is also statistically significant evidence that respondents who consider service quality above any other reasons will not only withdraw their funds from Islamic bank due to low service quality, but also due to non-Shari'ah compliant issues. This is perhaps because they consider Shari'ah issues are not only about the products per se but also services provided by Islamic banks. Table 2 and Table 3 provide evidences that withdrawal risk is one of the most potential risks to be mitigated in the future.

Table 3

Crosstab and Chi-Squared Independent Test between Main Reasons of Patronizing Islamic Bank and Withdrawal Action

\begin{tabular}{|c|c|c|c|c|c|c|c|c|c|c|}
\hline \multicolumn{4}{|c|}{$\begin{array}{c}\text { Non-Shari'ah compliant } \\
\text { issues }\end{array}$} & \multirow[t]{2}{*}{$\chi^{2}$-Stat } & \multicolumn{2}{|c|}{$\begin{array}{l}\text { Uncompetitive } \\
\text { rate of return }\end{array}$} & \multirow[t]{2}{*}{$\chi^{2}-$ Stat } & \multicolumn{2}{|c|}{$\begin{array}{c}\text { Low } \\
\text { service } \\
\text { quality }\end{array}$} & \multirow[t]{2}{*}{$\begin{array}{l}\chi^{2}- \\
\text { Stat }\end{array}$} \\
\hline & & & $\mathrm{N}-\mathrm{W}$ & & W & $\mathrm{N}-\mathrm{W}$ & & $\mathrm{W}$ & $\mathrm{N}-\mathrm{W}$ & \\
\hline To avoid & Yes & 85 & 50 & \multirow{2}{*}{$12 * *$} & 71 & 64 & \multirow{2}{*}{2.72} & 104 & 31 & 1.9 \\
\hline bank interest & No & 15 & 30 & & 30 & 15 & & 39 & 6 & 2 \\
\hline Competitive & Yes & 50 & 43 & \multirow[b]{2}{*}{0.25} & 64 & 29 & \multirow[b]{2}{*}{$12.6^{* *}$} & 77 & 16 & \\
\hline $\begin{array}{l}\text { Rate of } \\
\text { Return }\end{array}$ & No & 50 & 37 & & 37 & 50 & & 66 & 21 & $\begin{array}{c}1.5 \\
2\end{array}$ \\
\hline Good Service & Yes & 54 & 64 & \multirow{2}{*}{$13.3 * *$} & 68 & 50 & \multirow{2}{*}{0.32} & 100 & 18 & 5.8 \\
\hline Quality & No & 46 & 16 & & 33 & 29 & & 43 & 19 & $9 *$ \\
\hline
\end{tabular}

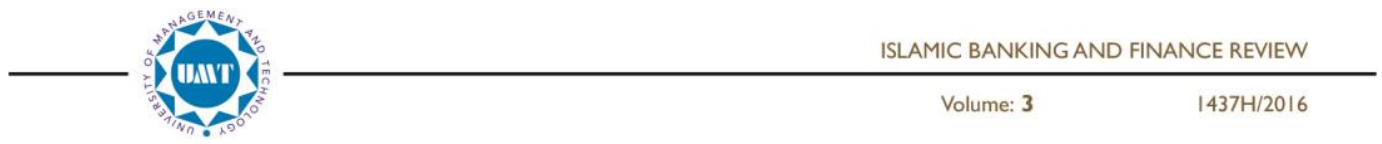


Note: "W" means Withdraw, "N-W" means Not Withdraw

\subsection{Reliability Test and Factor Analysis}

Cronbach's Alpha is used to test the reliability of the research instruments. The acceptable value of cronbach's alpha should be greater than 0.7 (Nunnelly and Bernstein, 1994). The result in Table 4 shows good estimation of the internal consistency reliability as the cronbach's alpha for "Importance" is 0.911 and for "Performance" is 0.875 .

\section{Table 4}

\begin{tabular}{lc} 
Reliability Analysis & \\
\hline & Cronbach's Alpha \\
\hline Importance & 0.911 \\
Performance & 0.875 \\
\hline
\end{tabular}

Principle component analysis based factor analysis is used to confirm that the observed variables are loaded correctly to their related latent variable. Table 5 confirms that all fifteen variables are loaded correctly to their related latent variable. Some are actually cross-loaded to other latent variables with various loading values. However, due to the highest loading values are still towards its related latent variables, thus the observed variables are said to be categorized correctly to its related latent variables. The findings from factor analysis that is the grouping of observed variables towards their latent variables are supported by previous findings by Zeithaml and Bitner (1996) and Abduh (2011).

Table 5

Factor Analysis

\begin{tabular}{|c|c|c|c|c|}
\hline Items & $\mathrm{V}-1$ & $\mathrm{~V}-2$ & $\mathrm{~V}-3$ & $\mathrm{~V}-4 \quad \mathrm{~V}-5$ \\
\hline The bank provides customers the services as promised & .873 & & & \\
\hline The bank provides accurate service to customers & .850 & & & \\
\hline $\begin{array}{l}\text { The bank honor their commitments when dealing with } \\
\text { customers }\end{array}$ & .837 & & & \\
\hline $\begin{array}{l}\text { Customers can feel a sense of security during the transaction } \\
\text { process }\end{array}$ & & .896 & & \\
\hline Staff understand the concept of Islamic contracts & & .870 & & \\
\hline Staff can provide customers prompt and appropriate services & & .845 & & \\
\hline $\begin{array}{l}\text { Staffs show compassion when handling complaints from } \\
\text { customers }\end{array}$ & & \multicolumn{3}{|c|}{.943} \\
\hline Staffs have enthusiasm to listen the customer needs & & \multicolumn{3}{|c|}{.883} \\
\hline Staffs consider customers' needs first before anything 1else & & \multicolumn{3}{|c|}{.857} \\
\hline Spacious parking area at the bank location & & \multicolumn{3}{|r|}{.895} \\
\hline Easy and fast to reach the bank's ATM location & & \multicolumn{3}{|r|}{.841} \\
\hline The bank's facilities and designs make customers feel & & \multicolumn{3}{|r|}{.840} \\
\hline & \multicolumn{4}{|c|}{ ISLAMIC BANKING AND FINANCE REVIEW } \\
\hline
\end{tabular}


comfortable

Bank charges for fund transfer or fund received

Bank charges for transactions using other banks’ ATM

Rates of return provided on deposit accounts

Note: Kaiser-Meyer-Olkin Measure of Sampling Adequacy is 0.845

Bartlett's Test of Sphericity is $1795.116(\mathrm{df}=105$; Sig. $=0.000)$

\subsection{Importance-Performance Analysis}

After confirming the latent variables, the observed variables were then grouped accordingly and merged into one variable by calculating the arithmetic average. Furthermore, in order to get the coordinate for all four quadrants, the grand arithmetic mean is calculated from both importance data as well as performance data. The grand arithmetic mean for importance and performance are 4.35 and 3.26 respectively.

Figure 2 shows that assurance and reliability dimensions fall into quadrant one which is "keep up the good work". It applies that the two dimensions have delivered their promises and fulfilled the expectation of the customers at these aspects. Interestingly, none of the service quality dimensions tested fall into quadrant two; possible over kill and area of high importance and high performance. Tangible is rated low in importance as well as in performance which makes it fall into quadrant three, that is low priority.

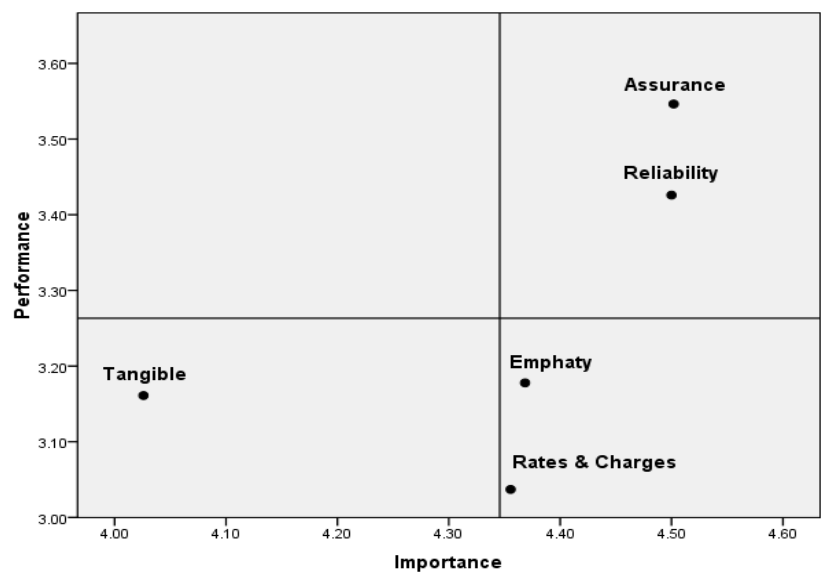

Figure 2. Output of importance-performance analysis

However, empathy as well as rates and charges dimensions were rated high in importance but low in performance and thus fall into quadrant "concentrate here". This implies that overkill has occurred and therefore, improvement must be done by Islamic banks for those dimensions. This situation must be catered wisely and 
properly due to the fact that there are more rational depositors than religious depositors patronizing Islamic banks in Brunei Darussalam. These depositors can anytime withdraw their fund and switch to conventional banks.

\section{Conclusion}

This study aimed at investigating the level of Brunei Darussalam Islamic banking service quality from the perspective of customers and its relationship with the customers' deposit withdrawal behavior. Using self-administered questionnaires distributed among Islamic banking customers in Bandar Seri Begawan, five dimensions service quality dimensions were confirmed by confirmatory factor analysis. These dimensions are; assurance, reliability, tangibles, empathy, and rates and charges.

Firstly, this study reveals that deposit withdrawal behavior is statistically and significantly influenced by the intentions of depositors in patronizing Islamic banks.

Secondly, out of the five bank services dimensions studied here, two are rated as high in both importance and performance; assurance and reliability. One is rated low in both importance and performance that is tangibles. Two are rated high in importance and low in performance; empathy and rates and charges.

Henceforth, this study provides findings that may benefit both Islamic banking practitioners and regulators by evaluating the quality of services provided so that they can take necessary actions to mitigate recurring bad situations.

Furthermore, any researchers interested to replicate this study in different geographical locations may get more robust findings by increasing the number of respondents and employing more sophisticated statistical methods such as logistic regression and structural equation model.

\section{References}

Abduh, M. (2011). Islamic Banking Service Quality and Withdrawal Risk: The Indonesian Experience. International Journal of Excellence in Islamic Banking and Finance, Vol. 1, No. 2, pp. 1-15.

Abduh, M. (2014). Withdrawal Behavior of Malaysian Islamic Bank Customers: Empirical Evidence from Three Major Issues. Journal of Islamic Banking and Finance, Vol. 31 No. 4, pp. 43-54.

Abduh, M., and Omarov, D. (2013). Muslim's Awareness and Willingness to Patronize Islamic Banking in Kazakhstan. Journal of Islamic Banking and Finance, Vol. 30 No. 3 (Jul.- Sept.), pp. 16-24.

Abduh, M.,Kassim, S.H., and Dahari, Z. (2012). Customer Satisfaction and Switching Behavior in Islamic Banking: Evidence from Indonesia. School of Doctoral Studies (Europian Union) Journal, Vol. 4, pp. 209-215. 
Abduh, M.,Kassim, S.H., and Dahari, Z. (2013). Factors Influence Switching Behavior of Islamic Bank Customers in Malaysia. Journal of Islamic Finance, Vol. 2, No. 1, pp. 12-19.

Ahmed, H. (2002). A Microeconomic Model of an Islamic Bank. Jeddah: Islamic Research and Training Institute.

Berry, L.L., Parasuraman, A. and Zeithaml, V.A. (1985). Quality counts in services, too. Business Horizons, May-June, pp. $44-52$.

Bolton, R.N. \&Bronkhurst, T.M. (1995).The relationship between customer complaints to the firm and subsequent exit behavior. Advances in Consumer Research, 22,92-100.

IFSB. (2016). Islamic Financial Services Industry Stability Report 2016. Kuala Lumpur: Islamic Financial Services Board.

Mahmoud, L.O.M. and Abduh, M. (2014). The Role of Awareness in Islamic Bank Patronizing Behavior of Mauritanian: An Application of TRA. Journal of Islamic Finance, Vol. 3 No. 2, pp. 30-38.

Nunnelly, J.C. and I.H. Bernstein, 1994. Psychometric Theory. 3rd Edn. New York: McGraw-Hill.

Parasuraman, A., Zeithaml, V.A. and Berry, L.L. (1985). A conceptual model of service quality and implications for future research. Journal of Marketing, Vol. 49 No. 4, pp. $41-50$.

Parasuraman, A., Zeithaml, V.A. and Berry, L.L. (1990). Delivering Quality Service: Balancing Customer Perception and Expectations. New York: The Free Press.

Suryani, T. and Chaniago, H. (2011). Switching Barrier Factors in Islamic Banking and the Effects on Customer Retention (July 9, 2011). Available at SSRN: http://ssrn.com/abstract=1882304

Zeithaml, V.A. and Bitner, M.J. (1996). Services Marketing. New York: McGrawHill. 